\title{
THE USE OF PICTORIAL MEDIA CARD TO IMPROVE THE INITIAL READING ABILITY OF SLOW LEARNER STUDENTS
}

\section{Rahma Widyana \& Nurani Sinta Dewi}

Fakultas Psikologi, Universitas Mercu Buana Yogyakarta, Jl. Raya Wates-Jogjakarta, Karanglo, Argomulyo, Kec. Sedayu, Bantul, Yogyakarta 55752, Indonesia

Korespondensi: rahma@mercubuana-yogya.ac.id

\section{PENGGUNAAN MEDIA KARTU BERGAMBAR UNTUK \\ MENINGKATKAN KEMAMPUAN MEMBACA AWAL SISWA SLOW LEARNER}

\begin{abstract}
Abstrak
Penelitian ini bertujuan untuk mengetahui penggunaan media kartu bergambar untuk meningkatkan kemampuan membaca permulaan siswa slow learner. Hipotesis penelitian ini adalah terdapat peningkatan yang signifikan terhadap kemampuan membaca permulaan pada anak slow learner setelah mendapatkan intevensi media kartu bergambar. Desain penelitian ini adalah eksperimen pretest posttest kelompok tunggal. Hasil uji Wilcoxon menunjukkan bahwa terdapat perbedaan skor kemampuan membaca permulaan sebelum dan sesudah diberikan intervensi, yaitu skor kemampuan membaca setelah memperoleh intervensi media kartu bergambar lebih tinggi daripada sebelum intervensi. Dengan demikian, penelitian ini menunjukkan bahwa penggunaan media kartu bergambar meningkatkan kemampuan membaca permulaan pada anak slow learner di kelas awal sekolah dasar.
\end{abstract}

Manuscript type: Brief Report

Article history:

Received 22 June 2020

Received in revised form 17 August 2020

Accepted 18 November 2020

Available online 21 December 2020

\section{Kata Kunci:}

kemampuan membaca permulaan

media kartu bergambar

siswa slow learner

\begin{abstract}
This study determines the use of pictorial media to improve the initial reading ability of slow learners. The research hypothesizes that a significant increase in reading abilities will occur after receiving the pictorial cards as an intervention's media. This study applies a pretest-posttest single group design. Wilcoxon's test analysis showed that there were differences in initial reading ability scores before and after the intervention. The reading ability scores after using the pictorial card media were higher than before the intervention. Therefore, the pictorial media was able to improve the initial reading ability of slow learners based on this study's samples of elementary students with poor reading skills.
\end{abstract}

Keywords: initial reading ability, pictorial card media, slow learner students

\section{Impact and Implication in the Indigenous Context}

The reading ability of slow learners, particularly students with poor initial reading skills in Indonesia is a rarely studied area, despite low literacy levels that is still pervasive in many parts of the country. Focusing on the reading abilities of slow learners at SD Negeri Pacitan, a majority of students required reading ability enhancements through an effective and non-conventional teaching method. The SD Negeri Pacitan school does not enrol students with learning disabilities. However, the teachers were incompetent in handling students with slower learning capacities because they apply the same teaching methods in class, regardless of the children's abilities. This research generates knowledge about pictorial cards as the media of intervention, serving as an alternative way to improve students' reading abilities that may be useful within the Indonesian teaching context. 


\section{INTRODUCTION}

Academically slow learners are usually identified based on their intelligence test scores, with IQs between 75-89 (Najma et al., 2012). Low intelligence reduces their learning speed and comprehensive abilities, so teaching elements for slow learners tend to focus on enhancing motivation, individual attention, and restoration. Slow learners rely on concrete rather than abstract learning. According to Mumpuniarti (2017), there are three groups of literacy abilities of slow learners. The first group are students who are unable to memorize the letters A to Z, read individual words, and still with spelling. The second group consists of students who experience pronunciation problems and difficulty in reading complex words. The third group are students who read sentences slowly and often repeat them. These skills are considered substandard to the student's level in the phase of spelling words. The participants of this research had characteristics of the second and third group, i.e. problems in reading complex words and comprehension mastery.

In this study, the low reading ability in slow learners were improved by using pictorial card media. According to Najma et al. (2012), factors that cause learning difficulties include limited concentration and attention levels, reduced ability in self-regulated learning, inability to abstract and generalize concrete experiences, as well as slower recognition and ability to relate words and meanings. Hence, using a pictorial method to enhance young reader's reading skills is deemed more effective than using text alone.

Levie and Lentz (1982) proposed four functions of pictorial media. First is the attention function, in which an interesting picture is used to capture concentration through a given lesson. The second function is affection because images arouse the emotions of learners. The third is the cognitive function involving pictorial media, which facilitates the achievement of goals to retain information. The fourth is compensatory function, in which pictorial media helps students with poor reading skills to organize and memorize information in a text. Therefore, the written text is changed into pictures so that students may easily understand and not easily forget. These functions make the pictorial media a potentially appropriate teaching instrument for slow learners to learn how to read. Pictorial media activates the visual senses of slow learners, enabling the students to remember the material learned without the pressures of traditional classroom learning.

Engaging media and repetition of material is the basis of success for slow learners, in terms of initial reading abilities. Shaw (2010) stated that slow learners comprehend concrete material faster than abstract information, primarily through repetition or remedial studies. The pictorial cards 
improve the initial reading ability for slow learners, as this media is distinctively more interesting, cognitively stimulating, and easily arouses emotions during the learning process. Therefore, slow learners do not quickly forget the material learned. This study hypothesized that the initial reading ability of slow learners based on a sample of elementary school children would improve after administration of picture cards as an intervention media.

\section{METHOD}

\section{Participants}

The participants sampled in this study consisted of five $2^{\text {nd }}$ Grade children at one of Pacitan City's elementary school. The children were identified as slow learners (IQ range between 80-90; WISC scale) and demonstrated low reading abilities (screened through the Early Reading Skill Test [Widyana et al., 2010]), without prior diagnoses of intellectual disabilities or comorbid neurodevelopmental conditions. The participants' identities and reading ability test scores are presented in Table 1.

Table 1.

Identity and Reading Ability Test Score

\begin{tabular}{ccccc}
\hline \multirow{2}{*}{ Participant } & Age & Gender & $\begin{array}{c}\text { IQ } \\
\text { (WISC Scale) }\end{array}$ & Initial reading score \\
\hline AFB & 8 years 3 months & Male & 88 & $17.09 \mathrm{kpm}$ \\
AL & 8 years 1 month & Female & 80 & $9.56 \mathrm{kpm}$ \\
M & 8 years & Female & 84 & $10.76 \mathrm{kpm}$ \\
RAC & 8 years 5 months & Male & 87 & $17.26 \mathrm{kpm}$ \\
SF & 7 years 10 months & Female & 86 & $20.10 \mathrm{kpm}$ \\
\hline
\end{tabular}

\section{Design}

This study applied a pretest-posttest single group design. The study was conducted on the same group, with outcomes analyzed based on scores measured before (pretest) and after the intervention (posttest). The posttest was conducted 2 days after the intervention. The instruments were 20 pieces of $18 \times 13 \mathrm{~cm}$ pictorial cards, which was a reasonable and comfortable size for the children to hold while reading. The pictures on the cards were large and colourful to attract the children's interest in learning, and to also prevent them from getting bored easily. The writing on the cards were adjusted to enable easy reading. In the third session, sentences were read and matched with random pictures. The study lasted 25 minutes in each meeting with a 5-minute break. 


\section{Procedure}

The intervention was conducted individually. One teacher and one observer accompanied each child participant. The observer recorded every word spoken by the participant. There are three steps in this intervention with each step using the pictorial cards to improve initial reading ability which is described below.

\section{First Step}

The teacher showed a pictorial card and writings that matched the pictures to the participants. The participants were asked to read the words in the picture. In case the participant struggled to read, or errors in reading occurred, the teacher pronounced the correct sound of the word. The participants were then given a card with the same picture, but with some missing letters. They were asked to complete the missing letters in the word being read. The teacher corrected them when they made mistakes. The participants read the word repeatedly until they demonstrated fluency.

\section{Second Step}

The teacher showed a card containing a short sentence with a random picture. The participants had to read the sentence correctly, then match it with the right picture. The teacher corrected them when they made mistakes. After successfully reading the words and matching them with the right picture, the participants were asked to read all the sentences fluently and correctly.

\section{Third Step}

The teacher showed an illustrated short story. Participants were asked to read the entire short story and then answer the teacher's questions orally. They were assisted by the teacher in case they made errors.

\section{Instruments}

The WISC test was utilized to determine the participants' IQ level, while the reading performance was measured through Early Reading Skill Test (Widyana et al., 2010). The reading ability score in the Early Reading Skill Test was calculated using reading ability formula according to Tampubolon (1990) which involves reading comprehension and speed. Reading speed is the number of words that are read in units of minutes. Comprehension is the percentage of correct 
answers to questions related to reading material. A higher number of correct answers indicated increased reading comprehension. The formula below was used (Tampubolon, 1990):

$$
K M=\frac{K B}{S M: 60} \times \frac{P I}{100} K P M
$$

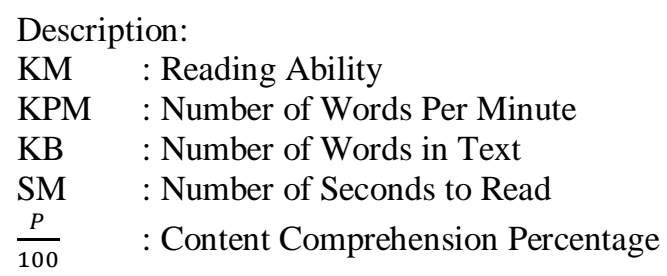

Widyana et al. (2010) describe the following characteristics of initial reading ability test as follows: 1) the test is in the short form of a reading text (at least 30-50 words per text), that was composed according to the level of language and knowledge of early elementary school children; 2) several multiple choice questions were presented to measure the child's ability to remember the text, also the questions were used to establish the children's level of knowledge outside the text; 3) the test is made in colour and illustrated with pictures, and as a result the children are more interested in the text and do not get bored quickly; and 4) the test has an answer sheet to record the number of errors and time spent to read by each child.

\section{Analysis Technique}

The Wilcoxon Signed Rank Test was used to analyze and examine the differences in reading ability scores before and after the intervention.

\section{ANALYSIS AND RESULTS}

Results of the Wilcoxon Signed Rank Test showed that there were significant differences in the initial reading ability before and after the treatment with the distribution of $\mathrm{z}$ scores of -2.023 ( $p$ $<.05)$. Participants' score means after the intervention were higher than prior to the intervention. Scores indicate that participants that were treated with the pictorial media method for learning experienced an increase in initial reading skills. Comparisons of initial reading ability before and after the treatment is presented in Diagram 1. 


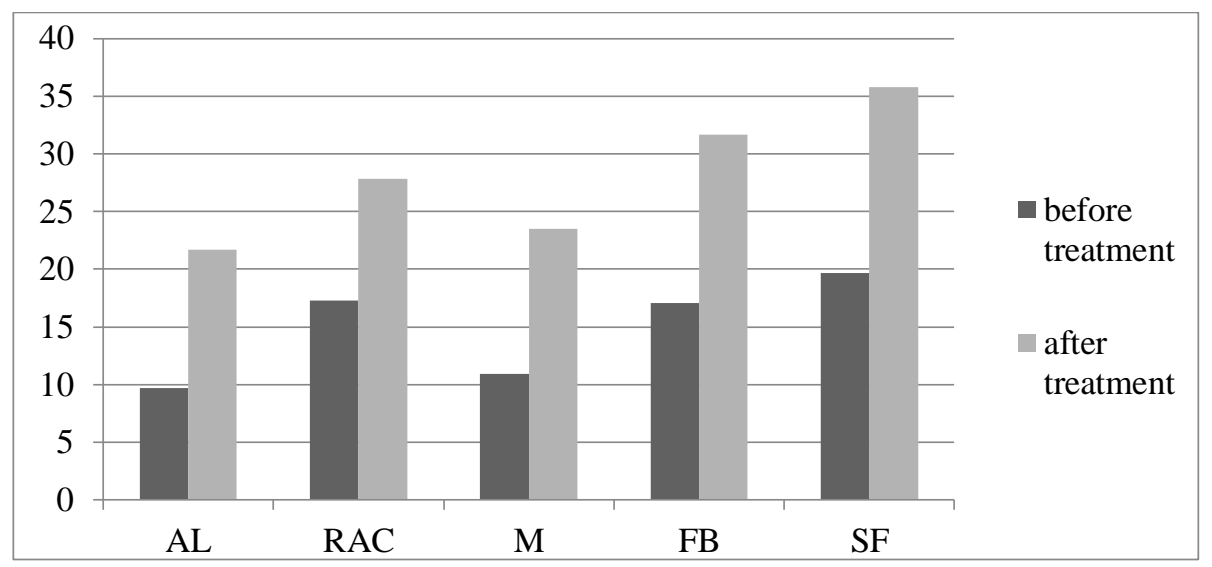

Diagram 1. Increases in Initial Reading Ability

Based on the diagram above, the five participants (Al, RAC, M, FB, and SF) have increased scores in the initial reading ability after receiving pictorial media treatment in 6 days. The scores, which include reading speed and comprehension before and after the intervention, are shown in Table 2.

Table 2.

Pre- and Post-Treatment Comparisons of Reading Ability Scores, Reading Speed and Reading Comprehension

\begin{tabular}{ccccccc}
\hline \multirow{2}{*}{ Participant } & \multicolumn{3}{c}{ Before the Intervention } & \multicolumn{3}{c}{ After the Intervention } \\
\cline { 2 - 7 } & KB $(\mathbf{k p m})$ & $\mathbf{P}(\boldsymbol{\%})$ & KM & KB (kpm) & $\mathbf{P}(\boldsymbol{\%})$ & KM \\
\hline AFB & 26.29 & 65 & 17.09 & 35.19 & 90 & 31.67 \\
AL & 23.91 & 40 & 9.56 & 28.87 & 75 & 21.65 \\
M & 23.90 & 45 & 10.76 & 29.34 & 80 & 23.47 \\
RAC & 28.75 & 60 & 17.26 & 34.82 & 85 & 29.60 \\
SF & 30.93 & 65 & 20.10 & 39.61 & 95 & 37.62 \\
\hline
\end{tabular}

Note: $\mathrm{KM}=$ Initial Reading Ability; KB = Reading Speed; P = Comprehension

Based on the results of comparisons between empirical data on reading ability scores, there are evident differences in reading speeds and comprehension before and after the pictorial media treatment. Participants showed increases in initial reading ability, as indicated by higher scores following the treatment. This showed that the pictorial media aided in enhancing the study participants' initial reading abilities, as measured through improved reading speed and comprehension.

From direct observation, the pictorial card media was able to help reduce the common reading mistakes in initial reading stages. According to Zubaidah (2013), there are nine errors that may occur in initial reading, including replacement of letters, words, word groups, omissions of 
letters, prefixes, syllables, words, letter addition, and suffixes. The errors above were also noticed in the participants in this study. The participants demonstrated similar errors, such as letter replacement, for instance, the word "ikan nila" (tilapia fish) to "ikan mila". The letter n was replaced with $\mathrm{m}$. Also, words were substituted, such as the "anjing sedang menggonggong" (a dog is barking) was read "anjing sedang ngong". This showed that participant had difficulties in reading the word "menggonggong", which may be too long or confusing. Therefore, the participant read only the end of the word. There were also additional pronunciation of letters, such as the word "delman" (horse carriage), which was read as "delaman", while "motor" became "montor". Furthermore, prefixes were omitted, such as the word "berwarna" (colored) to "warna", leaving out the prefix "ber". The participants also omitted suffixes. For instance, in the word "warnanya" (the color is), which became "warna", the suffix "nya" was omitted. Letter omission was also typical in the five participants during reading, such as the word "coklat" (chocolate), which became "colat". There was an omission of syllables, such as "ayam jantan berkokok" (a rooster crows), which was changed into "ayam jantan bekok". However, no participants demonstrated elimination of words or their groups. This indicated good results after the intervention for six meetings, each lasting one and a half hours, meaning that eight types of initial reading errors decreased. Therefore, the participant's initial reading ability improved.

\section{DISCUSSION}

Based on the results, the use of pictorial card media increased the initial reading ability of slow learners based on this study's samples of second grade students with predominantly poor reading skills, as reflected in the improved reading ability following treatment.

In each meeting, the participants followed the intervention orderly and diligently. Initially, most of the participants were shy, indicated by a low voice volumes, causing the instructor to ask them to repeat their answers loudly. On the first and second day, all participants read the words and sentences haltingly, making several errors. However, from the third day onwards, they began to show confidence and improved reading ability, evident through decreased reading errors. The participants also became jovial towards the facilitator, showing comfort by laughing and making jokes. The errors in reading words and sentences also continued to decrease. On the sixth day, participants had shown a significant improvement in reading ability. Participants RAC, AFB, AF, and SF had no errors in reading sentences, pictures, and pairing them, as well as completing words. 
The participants accomplished these tasks correctly and precisely. In the last session, which involved reading a sentence or a short story, participant $\mathrm{M}$ made one error. The sentence "anakanak bermain kucingan" (the children were role-playing as cats) was read as "anak-anak bermain kencingan". After receiving directions from the teacher, M managed to read and match the pictures correctly in the second attempt.

The participants' initial reading abilities significantly improved through the use of the pictorial media. The card media was able to reduce participants' reading and pronunciation errors. The underlying mechanism of reductions in reading errors could be explained by improvements in decoding and remembering words or text, meaning that the more accurate the decoding system, the better the reading ability of the participant. Therefore, increased reading speed results in better text comprehension (Rizkoh et al., 2014). Good recording and decoding are likely to be enhanced by pictorial media, which attracts children's interest in learning to read. This interest improved mental and emotional responses in the learning process, in addition to generating motivation and eliciting more active responses.

However, this study cannot overestimate the true magnitude of pictorial media within learning transfers due to the lack of an equivalent control group and possibility of confounders that played a role in enhancing the participants' reading skills (e.g. participants may naturally have visual learning styles; prefer to learn through non-conventional media; or have school-related anxiety that was managed with the presence of the facilitator or research team). In addition, interventions that were carried out by teachers or special education instructors may yield significantly different results (Rodriguez-Dorta \& Borges, 2017), as positive outcomes could be more pronounced when interventions are delivered by trained instructors who are familiar with special education teaching methods. Therefore, these issues introduce a certain degree of bias in this study.

The pictorial card media assumed the most effective method for improving initial reading ability, especially in slow learners. This is because the media resembles a realistic form of an object that easily enables children to remember what they learn. Also, visual learning helps students to develop thinking as a learning style. This improves their memory and comprehension ability by connecting words with images (Raiyn, 2018). Therefore, it is assumed that the child easily remembers and understands what has been learned.

According to the discussion above, the pictorial card media intervention increased the systematic recording and decoding accuracy among the participants. Also, the intervention reduced 
reading errors and increased speed, as well as text comprehension. This significantly influenced reading ability. Hence, the research hypothesis is accepted.

\section{CONCLUSION AND RECOMMEDATIONS}

\section{Conclusion}

In this study, the use of pictorial cards improved the initial reading ability for elementary school students who were considered slow learners based on their poor reading skills. Improvements in initial reading ability were measured through reductions in reading errors. However, current literature argues that differences in language or dialect may affect literacy acquisition, therefore we cannot infer that the pictorial card method is equally efficacious in every language or across multiple learning difficulties.

\section{Theoretical Recommendation}

Interpretation of this study's results are made with a focus on several methodological limitations. Firstly, the limited sample size of the study that included only five participants only in the second grade and without gradations on the severity of reading difficulties, therefore findings cannot be generalized to children in different ages, grade levels, or children with diagnosed learning or intellectual disabilities. Issues on other learning skills (e.g. mathematics, writing) were not assessed and thus require separate investigations. As, the intervention was conducted for only 6 days and lasted for only 25 minutes each day, future studies should extend the intervention time to more than 6 days (to measure for maintenance effects through longer intervention durations), with a control group, delivered and assigned with blinding and randomization to obtain more optimal and less biased results. The magnitude of effects can only be inferred to the treatment when adequate controls over biases are made.

\section{Practical Recommendation}

The evidence-based development of treatments for children with slow learning capacities are of profound importance due to the numerous skills that must be acquired in childhood. According to this study's results, pictorial media is recommended as one of the teaching methods of initial reading ability for slow learners specifically with poor reading skills. 


\section{REFERENCES}

Levie, W. H., \& Lentz, R. (1982). Effects of text illustrations: A review of research. Educational Communication and Technology Journal, 30, 195-232.

Mumpuniarti, M. (2017). Challenges faced by teachers in teaching literacy and numeracy for slow $\begin{array}{lllll}\text { learners. Journal of Sustainable Development, } & \text { 10(3), }\end{array}$ https://doi.org/10.5539/jsd.v10n3p243

Najma, I. M., Rehman, G., \& Hanif, R. (2012). Effect of academic interventions on the developmental skills of slow learners. Pakistan Journal of Psychological Research, 27(1), $135-151$.

Raiyn, J. (2018). The role of visual learning in improving students' high-order thinking skills. Journal of Education and Practice, 7(24), 115-121.

Rizkoh, F., Ohoiwutun, J. E., \& Thamrin, N. S. (2014). The implementation of speed reading technique to improve comprehension achievement. e-Journal of English Language Teaching Society (ELTS), 2(3), 1-15.

Rodriguez-Dorta, M. \& Borges, A. (2017). Behavioral pattern in special education: Good Teaching Practice. Frontiers in Psychology, 8(631), 1-13. https://doi.org/10.3389/fpsyg.2017.00631

Shaw, S. R. (2010). Rescuing students from the slow learner trap. Principal Leadership, 10(6), 1216.

Tampubolon. (1990). Kemampuan membaca: Teknik membaca efektif dan efisien. Angkasa.

Widyana, R., Safitri, R. M., \& Purnamasari, S. E. (2010). Validasi alat pengukuran (assesment tools) kemampuan membaca awal. Jurnal Insight, 8(1), 8-22.

Zubaidah, E. (2013). Kesulitan membaca permulaan pada anak: Diagnosa dan cara mengatasinya. Universitas Negeri Yogyakarta. 